\title{
Hyphotetical Learning Trajectory: Pemecahan Masalah Materi Sistem Persamaan Linear Dua Variabel
}

\author{
Raizal Rezky ${ }^{*}$, Ernawati Jais ${ }^{2}$ \\ 1 SMPN 1 Sampolawa, Buton Selatan \\ 2 Program Studi Pendidikan Matematika, FKIP, Universitas Dayanu Ikhsanuddin, Baubau \\ *email: raizalrezky.rr@gmail.com
}

\begin{abstract}
One of the goals of mathematics learning mentioned by NCTM is to become a mathematical problem solver. This indicates that students who study mathematics will have problem-solving abilities. In solving problems the things that need to be considered in learning are more about the process than the final result. If the final answer is emphasized, students can only learn one particular problem Furthermore, the important mathematical material is a two-variable linear equation system because the learning process in SPLDV requires good mastery of the material in problem solving, so from here it is necessary to design learning in order to formulate precisely the learning patterns that will be carried out by the teacher to students. This research uses design research method at the preliminary design stage which is arranged by considering students' ability to solve a mathematical problem at SMPN 1 Sampolawa, because each student has a different way of thinking between one student and another student. The flow of students' thinking that might appear in learning is called the hypothetical learning trajectory. In this article will explain the Hypothetical Learning Trajectory (HLT) in students' problem solving activities material systems of linear equations of two variables.
\end{abstract}

Keywords: Hypothesis Learning Trajectory; Problem Solving; SPLDV

\begin{abstract}
Abstrak
Salah satu tujuan pembelajaran matematika yang disebutkan oleh NCTM yakni menjadi problem solver matematika. Hal ini mengindikasikan siswa yang mempelajari matematika akan memiliki kemampuan pemecahan masalah. Dalam memecahkan masalah hal yang perlu diperhatikan dalam belajar adalah lebih mengutamakan proses dari pada hasil akhir. Jika jawaban akhir yang ditekankan maka siswa hanya dapat belajar satu masalah tertentu Selanjutnya materi matematika yang penting adalah sistem persamaan linear dua variabel (SPLDV) ini dikarenakan proses pembelajaran pada SPLDV memerlukan penguasaan materi yang baik dalam pemecahan masalah, sehingga dari sini diperlukan desain pembelajaran agar dapat merumuskan secara tepat pola pembelajaran yang akan dilakukan oleh guru kepada siswa. Penelitian ini menggunakan metode design research pada tahap preliminary design yang disusun dengan mempertimbangkan kemampuan siswa dalam menyelesaikan suatu masalah matematika di SMPN 1 Sampolawa, karena tiap siswa memiliki cara berpikir yang berbeda antara siswa satu dengan siswa yang lain. Alur berpikir siswa yang mungkin muncul dalam pembelajaran dinamakan dengan hipotesis lintasan belajar atau hypothetical learning trajectory. Dalam artikel ini akan memaparkan Hypothetical Learning Trajectory (HLT) dalam kegiatan pemecahan masalah siswa materi sistem persamaan linear dua variabel.
\end{abstract}

Kata Kunci: Hipotesis Lintasan Belajar; Pemecahan Masalah; SPLDV 


\section{PENDAHULUAN}

Matematika merupakan salah satu mata pelajaran wajib yang diajarkan di sekolah. Tujuan pembelajaran matematika agar siswa: (1) belajar menghargai matematika; (2) percaya diri dalam kemampuannya mengerjakan matematika; (3) menjadi problem solver matematika; (4) belajar untuk berkomunikasi secara matematika; (5) belajar untuk melakukan penalaran secara matematika (NCTM, 2000). Salah satu tujuan pembelajaran yang disebutkan pada poin 3 yakni menjadi problem solver matematika. Hal ini mengindikasikan siswa yang mempelajari matematika akan memiliki kemampuan pemecahan masalah.

Salah satu materi matematika yang penting adalah sistem persamaan linear dua variabel (SPLDV) ini dikarenakan proses pembelajaran pada SPLDV memerlukan penguasaan yang baik dalam pemecahan masalah, sehingga dari sini diperlukan desain pembelajaran agar dapat merumuskan secara tepat pola pembelajaran yang dilakukan oleh guru kepada siswa. Pentingnya materi SPLDV juga terlihat dari masuknya soalsoal SPLDV dalam ujian nasional yang diselenggarakan tiap tahunnya oleh pemerintah, akan tetapi ini berbanding terbalik dengan hasil yang didapatkan oleh siswa karena pada tahun 2019 presentase daya serap siswa secara nasional pada materi SPLDV di pokok pembahasan menentukan nilai variabel dari SPLDV hanya sebesar 34,40\% (Puspendik, 2019)

Penyelesaian permasalahan dalam SPLDV di SMP ini sangat beragam karena dalam proses untuk menemukan solusi yang tepat mempunyai beragam metode seperti metode grafik, metode subtitusi, metode eliminasi dan metode campuran. Akan tetapi dengan berbagai macam metode yang dapat digunakan ini masih terdapat siswa yang belum terbiasa menyelesaikan soal SPLDV tanpa petunjuk, berikut contoh soal dengan petunjuk.

Selesaikan SPLDV berikut dengan menggunakan metode subtitusi!

$$
\left\{\begin{array}{l}
2 x+3 y=15 \\
3 x-4 y=-5
\end{array}\right.
$$

Contoh soal yang tidak menggunakan petunjuk sehingga memberikan kebebasan kepada siswa dalam menemukan solusi dari system persamaan linear dua variabel dengan menggunakan metode yang dipelajari

Selesaikan Sistem Persamaan Linear Dua Variabel berikut ini!

$$
\left\{\begin{array}{l}
-x+5 y=23 \\
3 x-2 y=-17
\end{array}\right.
$$




\section{Mandalika Mathematics and Education Journal \\ Volume 2 Nomor 2, Desember 2020 \\ e-ISSN 2715-1190 | | p-ISSN 2715-8292 \\ DOI: http://dx.doi.org/10.29303/mandalika.v2i1.1780}

Oleh karena itu, perlu dikaji bagaimana design yang tepat bagi siswa untuk menyelesaikan system persamaan linear dua variabel, sehingga dengan design yang tepat dapat meningkatkan kemampuan pengetahuan siswa pada materi tersebut.

Dalam menyelesaikan suatu masalah matematika tiap siswa memiliki cara berpikir yang berbeda antara siswa satu dengan siswa yang lain. Hal ini didasarkan karena alur berpikir siswa yang berbeda. Alur berpikir siswa yang beragam ini harus menjadi perhatian penting bagi guru di dalam kelas. Sehingga guru perlu menyusun kemungkinan alur berpikir siswa dalam memecahkan suatu masalah matematika. Alur berpikir siswa yang mungkin muncul dalam pembelajaran dinamakan dengan Hyphotetical Learning Trajectory. Sehingga rumusan masalah dalam artikel ini adalah bagaimana hyphotetical learning trajectory dalam pemecahan masalah materi sistem persamaan linear dua variabel. Sedangkan tujuannya adalah untuk mendapatkan deskripsi alur berpikir siswa dalam pemecahan masalah materi sistem persamaan linear dua variabel. Dengan harapan dapat bermanfaat untuk pembelajaran matematika yang lebih inovatif dan pembelajaran yang lebih bermakna.

\section{METODE}

Penelitian ini merupakan penelitian desain penelitian (design research) yang berfokus pada tahap preliminary design. Tahap preliminary design ini merupakan tahap tentang hipotesis peneliti terhadap penelitian yang diteliti. Sehingga tahapan ini menjadi sangat penting untuk keberlanjutan penelitan ini. Penelitian ini dilaksanakan di SMPN 1 Sampolawa.

\section{HASIL DAN PEMBAHASAN}

\subsection{Kemampuan Pemecahan Masalah dalam Pembelajaran Matematika}

Pemecahan masalah merupakan satu aspek terpenting bermatematika. Pelajaran matematika diberikan di sekolah sejak dini dimaksudkan agar anak terampil menggunakan pengetahuan dan pengalamannya bermatematika untuk memecahkan masalah baik dari matematika sendiri maupun dari luar matematika. Hal ini sesuai dengan pendapat yang menyatakan bahwa matematika yang diajarkan pada jenjang pendidikan dasar dan jenjang pendidikan menengah yang bertujuan untuk menumbuh kembangkan kemampuan-kemampuan dan membentuk pribadi siswa melalui matematika (Suherman, et al, 2003). Melalui kegiatan ini pula kemampuan anak berpikir logis, kritis, kreatif, sistematis, dan analitis diasah dan dikembangkan. Menurut NCTM (2000) pentingnya kemampuan pemecahan masalah ini merupakan sarana mempelajari ide matematika dan terampil matematika. Kemampuan siswa tersebut mencakup merumuskan masalah, mempertimbangkan strategi dalam 
menyelesaikan masalah, menerapkan beragam strategi dalam penyelesaian masalah, serta dapat memverifikasi dan menggeneralisasi-kan hasil yang diperoleh (Polya, 1957).

Pembelajaran harusnya memungkinkan siswa membangun pengetahuan yang baru baginya melalui pemecahan masalah; masalah yang muncul dalam matematika atau disiplin lain; menerapkan dan mengadaptasikan berbagai strategi yang bersesuaian untuk memecahkan masalah; dan memonitor dan merefleksi atas proses pemecahan masalah matematik (NCTM, 2000). Pemecahan masalah adalah sarana seorang sebagai individu menggunakan pengetahuan yang diperoleh sebelumnya, keterampilan, dan pemahaman untuk menyelesaikan masalah pada keadaan yang tidak familiar (Krulik \& Rudnick, 1995). Selanjutnya bahwa matematika dibutuhkan untuk kebutuhan praktis dan memecahkan masalah dalam kehidupan sehari-hari sehingga proses pembelajaran matematika harus dirancang sedemikian rupa sehingga dapat menimbulkan minat, kreatifitas, keaktifan, motivasi belajar matematika serta sikap positif pada diri sendiri terhadap matematika (Suherman, et al, 2003). Pemecahan masalah seyogianya memberikan konteks di mana anak belajar konsep dan keterampilan. Selian itu pada abad 21 ini ada banyak keterampilan yang ditekankan dalam mencapai tujuan pendidikan, salah satunya adalah keterampilan pemecahan masalah. Keterampilan pemecahan masalah ini merupakan kompetensi keterampilan dari kurikulum 2013 yang meliputi kemampuan berpikir dan bertindak secara kreatif. Hal ini berarti terdapat hubungan antara kurikulum 2013 terhadap keterampilan abad 21.

Kemampuan pemecahan masalah merupakan kemampuan atau keterampilan siswa dalam menyelesaikan masalah kompleks dengan menerapkan konsep dan beragam kreativitasnya dalam mengerjakan non rutin, soal terbuka dan soal yang berkaitan dengan dunia nyata (Adams \& Hamm, 2010; Bell, 1978; Karatas \& Baki, 2013; NCTM, 2000; Nitko \& Brookhart, 2011). Kemampuan siswa tersebut mencakup merumuskan masalah, mempertimbangkan strategi dalam menyelesaikan masalah, menerapkan beragam strategi dalam penyelesaian masalah, serta dapat memverifikasi dan menggeneralisasi-kan hasil yang diperoleh (Polya, 1957).

Ada banyak strategi dalam pemecahan masalah dan karenanya guru dapat mengenalkannya satu demi satu sesuai dengan tingkat perkembangan mental siswa dan kebutuhan masalah yang dihadapi. Perlu diingat, strategi yang dikenalkan kepada siswa adalah alat bantu untuk memecahkan masalah. Oleh karenanya, tidak tertutup kemungkinan kalau siswa membuat cara atau jalannya sendiri yang bisa berbeda dari yang dikenalkan kepada mereka. Adapun beberapa strategi pemecahan masalah yang bisa digunakan guru dalam meningkatkan kemampuan pemecahan masalah siswa antara lain membuat gambar atau diagram, mencari pola serta menebak dan memeriksa. 
Hal yang perlu diperhatikan dalam belajar memecahkan masalah adalah lebih mengutamakan proses dari pada hasil akhir. Hal ini sejalan dengan pendapat Reys, et al yang mengatakan, kalau jawaban akhir yang ditekankan maka anak hanya dapat belajar satu masalah tertentu sedangkan bila proses yang jadi fokus maka anak berkecenderungan belajar memecahkan masalah-masalah lain (Reys, et al, 1998). Selain itu, memecahkan masalah sedapatnya merasuk pada seluruh topik dalam pelajaran matematika. Pemecahan masalah seyogianya memberikan konteks di mana anak belajar konsep dan keterampilan. Selanjutnya, agar pembelajaran pemecahan masalah berjalan efektif maka guru mesti memperhatikan waktu yang cukup bagi anak, bantuan terencana, sumber yang dibutuhkan, peran teknologi, dan pengaturan kelas. Dalam hal ini pemecahan masalah akan difokuskan pada pelaksanaan pembelajaran materi sistem persamaan linear dua variabel.

\subsection{Pemecahan Masalah Materi Sistem Persamaan Linear Dua Variabel}

Dalam proses penyelesaian masalah dalam system persamaan linear dua variabel (SPLDV) dengan menggunakan kemampuan pemecahan masalah yang mencakup 4 hal, terlebih dahulu siswa perlu mengetahui konsep dari SPLDV itu sendiri, sehingga di awal siswa perlu mampu membedakan yang mana contoh dan bukan contoh dari SPLDV tersebut. Berikut kami sajikan tahapan awal pengenalan contoh dan bukan contoh dari SPLDV

Dari contoh dibawah ini, manakah yang merupakan contoh bentuk sistem persamaan linear dua variabel?
a. $4 x+3 y=14$ dan $2 x+7 y=18$
b. $x^{2}+3 y=10$ dan $5 x-y=8$
c. $a=25-6 b$ dan $a+7 b=29$
d. $a+3 b=20$ dan $-a b+2 b=-7$

Gambar 1. Contoh dan bukan contoh soal SPLDV

Ketika siswa telah mampu membedakan contoh dan bukan contoh dari SPLDV di atas, maka selanjutnya siswa diarahkan untuk bagaimana menyelesaikan soal-soal SPLDV dalam kehidupan sehari-hari. Ini dikarenakan dari pengalaman yang ada masih banyak siswa yang merasa kesulitan dalam memecahkan masalah matematika dalam hal ini penerapan system persamaan linear dalam kehidupan sehari-hari.

Dari hal itu, untuk melihat alur belajar siswa, maka salah satu strategi yang dapat digunakan adalah pemecahan masalah yang dikemukakan oleh Polya, dimana terdapat empat hal yang perlu dilakukan oleh siswa yaitu merumuskan masalah, mempertimbangkan strategi dalam menyelesaikan masalah, menerapkan beragam 


\section{Mandalika Mathematics and Education Journal \\ Volume 2 Nomor 2, Desember 2020 \\ e-ISSN 2715-1190 | | p-ISSN 2715-8292 \\ DOI: http://dx.doi.org/10.29303/mandalika.v2i1.1780}

strategi dalam penyelesaian masalah, serta dapat memverifikasi dan menggeneralisasikan hasil yang diperoleh (Polya, 1957).

\section{Merumuskan masalah}

Dalam merumuskan atau memahami masalah hal-hal yang perlu dilihat adalah siswa masih banyak kesalahan dalam menuliskan diketahui dan ditanyakan. Pemikiran siswa langsung menuliskan jawaban dengan mengubahnya kedalam bentuk matematika.

\section{Merencanakan penyelasian masalah}

Dalam mempertimbangkan strategi atau merencanakan penyelesaian masalah, masih banyak dalam pemikiran siswa yang belum memahami konteks soal. Siswa langsung menjawab dengan apa yang ia pahami tapi belum mampu membuat model matematika dari apa yang ditanyakan.

\section{Melaksanakan rencana}

Pelaksanaan perencanaan yang dilakukan oleh siswa di SMP dapat dilakukan dengan 4 metode yaitu: (1) metode grafik, (2) metode subtitusi, (3) metode eliminasi, dan (4) metode subtitusi-eliminasi.

\section{Mengecek kembali}

Siswa bingung dalam melakukan pengecekkan kembali. Sehingga metode yang paling sering didapatkan oleh guru terhadap siswa yaitu siswa mengecek kembali hanya dengan membaca ulang apa yang telah dilakukannya dari awal hingga akhir.

\subsection{HLT dalam Pemecahan Masalah Materi SPLDV}

Desain pembelajaran dalam kelas merupakan rancangan yang digunakan sebagai acuan dalam pelaksanaan pembelajaran di kelas. Desain pembelajaran memberikan gambaran bagaimana pembelajaran akan dilaksanakan, hal ini termuat dalam Rencana Pelaksanaan Pembelajaran (RPP). RPP memuat aktivitas dari awal pembelajaran hingga berakhirnya pembelajaran yang dimulai dari kegiatan pembukaan, kegiatan inti dan kegiatan penutup. RPP yang demikian merupakan RPP yang bersifat formalitas (Wijaya, 2009). Seringkali RPP hanya menampilkan aktivitas guru dan siswa secara garis besar. Masih jarang ditemui guru yang menyiapkan hipotesis atau dugaan respon pemecahaan masalah yang siswa gunakan dalam pembelajaran di kelas. Sehingga menyebabkan pembelajaran terlihat kaku dan belum open ended.

Hyphotetical learning trajectory (HLT) merupakan alur dugaan pikiran siswa dalam mempelajari suatu topik. HLT juga menurut Clements dan Sarama (Rezky \& Wijaya, 2018) dapat memperlihatkan hubungan yang saling mempengaruhi antara kegiatan dan proses pembelajaran. Banyak alur dugaan yang dapat muncul dari siswa selama pembelajaran sehingga menurut Retnawati, et al (Rezky, 2019) diperlukan suatu proses 
pembelajaran yang perlu memperhatikan siswa dari baaimana siswa tersebut berpikir tentang matematika itu sendiri yang nantinya siswa dapat menghubungkan antara materi satu dan lainnya.

Hal ini sangat wajar terjadi mengingat siswa di dalam kelas heterogen. Banyak sekali perbedaan yang mungkin dapat muncul sebagai respon siswa. Dugaan ini digunakan sebagai jembatan antara teori pembelajaran yang sudah ada dengan aktivitas nyata siswa di kelas (Bakker, 2004). Hal ini dapat membantu guru sebagai fasilitator di kelas dapat memberikan pembelajaran yang dapat memfasilitasi keanekaragaman siswa dalam belajar.

Hal senada disampaikan oleh Simon (1995) yang menyebutkan bahwa komponen penyusun HLT ada 3 yakni tujuan pembelajaran, kegiatan belajar, dan hipotesis proses belajar. Tujusn pembelajaran mendefinisikan arah (tujuan pembelajaran) selama kegiatan pembelajaran di kelas, sedangkan untuk memprediksi bagaimana pikiran dan pemahaman siswa akan berkembang dalam konteks kegiatan belajar dilengkapilah dengan hipotesis. Hipotesis yang ada disusun berdasarkan teori pembelajaran dan pengalaman aktivitas di kelas yang sudah ada dan selanjutnya digunakan sebagai pacuan dalam pembelajaran. Sehingga dapat digunakan sebagai alat pemverifikasi antara teori pembelajaran dan aktivitas nyata siswa. Dalam hal ini hipotesis yang akan disusun mengenai pemecahan masalah dalam menyelesaikan materi sistem persamaan linear dua variabel.

Pemecahan masalah yang dikemukakan oleh Polya (1957) terdapat empat hal yang perlu dilakukan oleh siswa. Dalam menyelesaiakan SPLDV dengan pemecahan masalah teori Polya, keempat hal yang dilakukan ini terdapat hipotesis atau dugaan alur berpikir siswa yang mungkin muncul selama pemecahan masalah berlangsung. Hipotesis atau dugaan alur berpikir siswa yang mungkin muncul dalam memecahkan masalah SPLDV adalah sebagai berikut:

\section{Merumuskan masalah}

Dalam merumuskan masalah, siswa harus mampu memahami apa saja informasi yang ada dan apa saja hal yang perlu dicarikan solusi masalahnya. Akan tetapi siswa masih banyak kesalahan dalam menuliskan informasi yang ada yakni informasi yang diketahui dan permsalahan apa yang ditanyakan. Seringkali pemikiran siswa langsung menuliskan jawaban dengan mengubahnya kedalam bentuk matematika. Hipotesis atau dugaan alur berpikir siswa dalam merumuskan masalah SPLDV adalah sebagai berikut:

1. Siswa dapat menemukan informasi yang diketahui dan memahami permasalahan yang perlu dicarikan solusinya. Kemudian siswa dapat menentukan langkah selanjutnya. 
2. Siswa dapat menemukan informasi yang diketahui dan memahami permasalahan yang perlu dicarikan solusinya akan tetapi siswa belum dapat menentukan langkah selanjutnya.

3. Siswa dapat menemukan informasi yang diketahui namum belum dapat memahami permasalahan yang perlu dicarikan solusinya dan belum dapat menentukan langkah selanjutnya.

4. Siswa belum dapat menemukan informasi yang diketahui namun dapat memahami permasalahan yang perlu dicarikan solusinya, dan siswa belum dapat menentukan langkah selanjutnya.

5. Siswa belum dapat menemukan informasi yang diketahui, belum dapat memahami permasalahan yang perlu dicarikan solusinya, dan belum dapat menentukan langkah selanjutnya.

\section{Merencanakan penyelasian masalah}

Setelah mampu merumuskan masalah maka langkah selanjutnya yakni mempertimbangkan strategi atau merencanakan penyelesaian masalah. Banyak sekali kemungkinan aktivitas siswa yang mungkin muncul. Tidak jarang ditemui masih banyak dalam pemikiran siswa yang belum memahami konteks soal, sehingga siswa langsung menjawab dengan apa yang ia pahami tapi belum mampu membuat model matematika dari apa yang ditanyakan. Hipotesis atau dugaan alur berpikir siswa dalam merencanakan penyelesaian masalah SPLDV adalah sebagai berikut:

1. Siswa dapat memodelkan informasi yang diketahui dan dapat memodelkan informasi yang ditanyakan. Kemudian siswa dapat menentukan langkah selanjutnya.

2. Siswa dapat memodelkan informasi yang diketahui dan dapat memodelkan informasi yang ditanyakan. Akan tetapi siswa belum dapat menentukan langkah selanjutnya.

3. Siswa dapat memodelkan informasi yang diketahui namun belum dapat memodelkan informasi yang ditanyakan, dan belum dapat menentukan langkah selanjutnya.

4. Siswa belum dapat memodelkan informasi yang diketahui namun dapat memodelkan informasi yang ditanyakan, dan belum dapat menentukan langkah selanjutnya.

5. Siswa belum dapat memodelkan informasi yang diketahui dan belum dapat memodelkan informasi yang ditanyakan, serta belum dapat menentukan langkah selanjutnya.

\section{Melaksanakan rencana}

Pelaksanaan perencanaan yang dilakukan oleh siswa di SMP dalam memecahkan masalah SPLDV dilakukan dengan 4 metode yaitu: (1) metode grafik, (2) metode subtitusi, (3) metode eliminasi, dan (4) metode subtitusi-eliminasi. Hipotesis atau dugaan alur berpikir siswa dalam melaksanakan merencanakan penyelesaian masalah SPLDV adalah sebagai berikut:

1. Siswa menggunakan metode grafik untuk menentukan nilai kedua variabel. 


\section{Mandalika Mathematics and Education Journal \\ Volume 2 Nomor 2, Desember 2020 \\ e-ISSN 2715-1190 | | p-ISSN 2715-8292 \\ DOI: http://dx.doi.org/10.29303/mandalika.v2i1.1780}

2. Siswa menggunakan metode subsitusi untuk menentukan nilai kedua variabel.

3. Siswa menggunakan metode eliminasi untuk menentukan nilai kedua variabel.

4. Siswa menggunakan metode eliminasi untuk menentukan nilai variabel pertama dan menggunakan subsitusi untuk menentukan nilai variabel kedua.

Mengecek kembali

Untuk melakukan tahap akhir dari keempat langkah dalam pemecahan masalah adalah dengan memverivikasi atau mengecek ulang untuk mengetahui hasil dari pemecahan masalah yang sudah dilakukan. Metode yang paling sering didapatkan oleh guru terhadap siswa yaitu siswa mengecek kembali hanya dengan membaca ulang apa yang telah dilakukannya dari awal hingga akhir. Akan tetapi masih banyak kemungkinan lai yang digunakan oleh siswa. Hipotesis atau dugaan alur berpikir siswa dalam pengecekan kembalin penyelesaian masalah SPLDV adalah sebagai berikut:

1. Membaca ulang kegiatan pemecahan masalah yang sudah dilakukan dari awal hinga akhir.

2. Mensubsitusikan nilai variabel ke salah satu persamaan.

\section{PENUTUP}

Berdasarkan uraian hyphotetical learning trajectory dalam pemecahan masalah materi SPLDV dapat ditarik simpulan bahwa guru dapat mendesain pembelajaran SPLDV dengan mempertimbangkan hyphotetical learning trajectory yang dimiliki siswa agar siswa dapat memecahkan masalah SPLDV dan guru dapat menentukan strategi pembelajaran yang dapat membatu siswa dalam memecahkan masalah SPLDV dengan mempertimbangkan hyphotetical learning trajectory yang dimiliki siswa serta siswa dapat terfasilitasi dengan alur berpikir yang beragam dalam memecahkan masalah SPLDV dengan adanya hyphotetical learning trajectory.

\section{UCAPAN TERIMA KASIH}

Ucapan terima kasih kepada Kepala SMPN 1 Sampolawa, Dekan FKIP Unidayan Baubau, Ketua Program Studi Pendidikan Matematika Unidayan Baubau, dan pihakpihak lain yang tidak dapat disebutkan satu per satu yang telah membantu penulis hingga artikel ini dapat disusun dan terselesaikan.

\section{REFERENSI}

Adams, D., \& Hamm, M. (2010). Demystify math, science, and technology: creativity, innovation, and problem solving. Lanham: Rowman \& Littlefield Publishing Group, Inc.

Bakker, A. (2004). Design research in statistics educationalon simbolizing and computer tools. Amersfoort: Wilco Press.

Bell, F. H. (1978). Teaching and learning mathematics: In secondary school. Dubuque: Wm. C. Brown Company Publishers 
Karatas, I., \& Baki, A. (2013). The effect of learning environments based on problem solving on students' achievements of problem solving. International Electronic Journal of Elementary Education, 5(3), 249-268.

Krulik, S. \& Rudnick, J.A. (1995). The New sourcebook for teaching reasoning and problem solving in elemntary school. Boston: Allyn \& Bacon.

NCTM. (2000). Principle and Standards for School Mathematics. Reston: Viginia

Nitko, A. J., \& Brookhart, S. M. (2011). Educational assessment of student. New Jersey: Pearson Education.

Polya, G. (1957). How to solve it: A new aspect of mathematical method. New Jersey: Princeton University Press

Puspendik. (2019). Laporan Hasil Ujian Nasional. Puspendik.kemendikbud,go.id/hasil-un/

Reys, R.E. et al. 1998. Helping Children Learn Mathematics. 5th. ed. Needham Heights: Allyn \& Bacon.

Rezky, R. (2019). Hypothetical Learning Trajectory ( HLT ) dalam Perspektif Psikologi Belajar Matematika Hypothetical Learning Trajectory ( HLT ) in Psychology Learning Mathematics Perspective. Ekspose: Jurnal Penelitian Hukum Dan Pendidikan, 18(1), $762-769$

Rezky, R., \& Wijaya, A. (2018). Designing hypothetical learning trajectory based on van hiele theory: a case of geometry. Journal of Physics: Conference Series, 1-10

Simon, M.A. (1995). Recontructing mathematics pedagogy from a contructivist persective. Journal for Research in Mathematics Education, 26, 114-145.

Suherman, E., Turmudi., Suryadi, D., Suhendra, H., Sufyani., Prabawanto., Nurjanah, \& Rohayati, A. (2003). Strategi pembelajaran matematika kontemporer. Bandung: JICA.

Wijaya, A. (2009). Hypothetical learning trajectory dan peningkatan pemahaman konsep pengukuran panjang. Makalah disajikan dalam seminar nasional matematika dan pendidikan matematika FMIPA UNY, 5 Desember 2009. 